\title{
EFFECTS OF MERGERS AND ACQUISITIONS ON B\&H BANKING SECTOR DEVELOPMENT
}

\author{
Vesna Babic-Hodovic \\ Eldin Mehic
}

\begin{abstract}
The main objective of this paper is to analyze the level, structure and effects of FDI in the form of $M \& A$ into the banking sector in Bosnia and Herzegovina. The goal was to show positive effects of growing levels of $M \& A$ in banking, but at the same time gaps and problems that $B \& H$ still faces. We also compare $B \& H$ with other countries in the region to determine whether there are significant differences, lessons or consequences of the large share of foreign owned banks for $B \& H$.

The results indicate that effects of increasing $M \& A$ (FDI) in the banking sector in $B \& H$ and the region have been positive. But, the price paid for this has been increased concentration, leading to a region's dependence on a decreasing number of foreign banks, with a possible increase in systemic risk and monopolistic behavior. Still, the lessons are clear: reforms and opening up of domestic markets have spurred growth and development of the banking sector. However, there is a need for countries to insist on good corporate behavior, as well as careful monitoring of potential anti-competitive behavior.
\end{abstract}

Key words: FDI, M\&A, banking sector development, $B \& H$

\section{INTRODUCTION}

Foreign direct investments (FDI) are a crucial element for development of modern economies. FDI role in globalization is unquestionable; the countries, which receive the most FDI, develop faster. Evaluating development of specific sectors in transitional countries is important in understanding the effects of FDI both theoretically and practically. This is particularly important considering that the further economic development of transitional economies significantly depends on foreign capital inflows.

Two basic FDI forms are: green-field investments and mergers and acquisitions (brown-field investment). Main difference between the two of them is the fact the M\&A change ownership of existing business entities, while the overall number of entities remains unchanged. That means that, at least in the first stage, M\&A do not contribute to growth of business or production capacities in the host country. Therefore it is possible to conclude that M\&A are less beneficial for the overall development of the country, in comparison with the green-field ones. At the same time, looking at the forms of FDI, we can conclude that prevailing form of FDI are the M\&A.

This paper looks at the level, structure and effects of FDI in the banking sector in Bosnia and Herzegovina $(\mathrm{B} \& \mathrm{H})$. The focus is on the mergers and acquisitions as the prevailing form of FDI in B\&H banking sector. The goal of the paper is to show the positive effects of the growing level of M\&A in banking (as prevailing form of FDI), but at the same time identifies the gaps and problems $\mathrm{B} \& \mathrm{H}$ still faces. The paper incorporates comparison of $\mathrm{B} \& \mathrm{H}$ with other countries in the region, to determine whether there are significant differences, lessons or consequences of the large share of foreign owned banks for BiH.

\section{BACKGROUND OF B\&H BANKING SECTOR}

The current State of Bosnia and Herzegovina came into existence after an independence referendum in 1992, which precipitated a devastating war that ended with the signing of the Dayton Peace Accords on the 24 December 1995. B\&H structured of two separate Entities (the Federation of B\&H or Federation and the Serb Republic or RS). The Accords (US Department of State, 1995) set up a State level Central Bank to replace the three that functioned during the war. (Tesche, 2002; 3-4) The Law on the Central Bank was adopted in June 1997.

Although the Central Bank is at the State level, bank regulatory agencies are not. Each Entity has its own regulatory agency. The Federation Banking Agency (FBA) is responsible for bank licensing and supervision. In the RS, the National Bank of RS was responsible until the Banking Agency (BARS) was set up 
mid-1998. In the Federation, the minimum level of bank capital was set at KM 5 million to be reached by April 1999. Amendments were passed in 2000 to increase this in steps to KM 15 million by the end of 2002, or by October 2000 for new banks. The 1996 Banking Law in the RS required the equivalent of US\$ 1.5 million capital. The banking law of July 1999 raised this to KM 5 million effective January 2000. It was raised again to 15 million KM in 2002 (Tesche, 2002; 12). In contrast, the minimum level of bank capital in Croatia is 40 million Kuna, or about 11 million KM. The banking system remained quite weak and undercapitalized until after 2000, but the reforms set the stage for the rapid increase in FDI in the banking sector in $\mathrm{B} \& \mathrm{H}$ thereafter.

\section{THEORETICAL BACKGROUND}

M\& A, as the one of two basic forms of FDI, can be implemented in the form of an in-market or a crossmarket transaction. In-market transactions have been most intense in the commercial banking sector, notably retail banking. Extensive banking overcapacity in some countries has led to substantial consolidation that has often involved M\&A activity. Many of banking M\&A are cross-border activities. During 1985-2002, most of M\&A transactions in financial services sector were in-market (that is, within banking, insurance, securities, and so forth), with firms acquiring or merging with similar firms, rather than cross-market (between generic activities) as the next table shows.

\section{Motives for M\&A}

The value of taking over an existing entity for the acquirer could be expressed as the present value of the target's earnings and the discounted growth opportunities the target offers. (Walter, 2004; 62-79) As long as the expected rate of return on those growth opportuni- ties is greater than the cost of capital, the merged entity creates value and the merger should be considered. From the perspective of the shareholders, M\&A transaction must contribute to maximizing the franchise value of the combined firm. This means maximizing the risk-adjusted present value of expected net future returns. Consequently, the main motives for $\mathrm{M} \& \mathrm{~A}$ are (Walter, 2004; 62-79):

$\checkmark$ Market extension. A firm wants to expand geo graphically into markets in which it has traditional ly been absent or weak, or it wants to broaden its product range because it sees attractive opportuni ties that may complement its existing activities. Done successfully, such growth through acquisi tion should be reflected in both the top and bottom lines and reflected in both market share and prof itability. (Walter, 2004; 62)

$\checkmark$ Economies of scale. Whether economies of scale exist in financial services has been at the heart of strategic and regulatory discussions about optimum firm size in the financial services industry. (Walter, 2004; 64) If economies of scale prevail, increased size will help create shareholder value and sys temic financial efficiency. If diseconomies prevail, both will be destroyed.

$\checkmark$ Cost economies of scope. M\&A activity may also be aimed at exploiting the potential for economies of scope in the financial services sector - competi tive benefits to be gained by selling a broader rather than narrower range of products - which may result either in cost reduction or in revenue increase. (Walter, 2004; 66) Most empirical studies have failed to find cost economies of scope in banking, insurance, or securities industries. The majority of such studies have concluded that some diseconomies of scope are encountered when firms in the financial services sector add new product ranges to their portfolios.

$\checkmark$ Operating efficiencies. Financial firms of roughly the same size and providing roughly the same

Table 1: Volume of In-Market mergers and Acquisitions in the United States and Europe, 1985-2002

(billions of U.S. \$ and \%)

\begin{tabular}{|l|l|l|l|l|l|l|l|l|l|l|}
\hline \multicolumn{3}{|c|}{ WORLD TOTAL } & \multicolumn{3}{c|}{ U.S } & \multicolumn{3}{c|}{ EUROPA } \\
\hline $\begin{array}{l}\text { Acquiring } \\
\text { institution }\end{array}$ & Banks & Securities & Insurance & Banks & Securities & Insurance & Banks & Securities & Insurance \\
\hline $\begin{array}{l}\text { Commercial } \\
\text { banks }\end{array}$ & $\begin{array}{l}1260 \\
(52.2 \%)\end{array}$ & 71 & 63 & 594 & 30 & 0.3 & 370 & 24 & 52 \\
\hline $\begin{array}{l}\text { Securities } \\
\text { firms }\end{array}$ & 111 & 282 & $(2.6 \%)$ & $(50.94 \%)$ & $(2.6 \%)$ & $(0.0 \%)$ & $(47.5 \%)$ & $(3.1 \%)$ & $(6.7 \%)$ \\
\hline $\begin{array}{l}\text { Insurance } \\
\text { companies }\end{array}$ & $(4.6 \%)$ & $(11.7 \%)$ & $(4.0 \%)$ & $(1.2 \%)$ & $(15.6 \%)$ & $(4.2 \%)$ & $(6.8 \%)$ & 48 & 39 \\
\\
\hline
\end{tabular}

Source: Walter, Ingo, (2004) Mergers and Acquisitions in Banking and Finance, Oxford University press, 45 Based on Thomson Financial Securities Data 
range of services can have very different cost lev els per unit of output. Empirically, a number of authors have found very large disparities in cost structures among banks of similar size, suggesting that the way banks are run is more important than their size or the selection of businesses that they pursue. (Walter, 2004; 67).

$\checkmark$ Revenue Economies of Scope. On the revenue side, economies of scope attributable to cross-sell ing arise when the overall cost to the buyer of mul tiple financial services from a single supplier is less than the cost of purchasing them from separate suppliers. Demand-side economies of scope include the ability of clients to take care of a broad range of financial needs through one institution - a convenience that may mean they are willing to pay a premium. (Walter, 2004; 69)

$\checkmark$ In addition to the strategic search for operating economies and revenue synergies, financial servic es firms will also seek to dominate markets in order to extract economic returns. By focusing on a par ticular market, merging financial firms could increase their market power and thereby take advantage of monopolistic or oligopolistic returns. Market power allows firms to charge more or pay less for the same service. (Walter 2004; 76).

Those motives lead to the growing trend of the M\&A, as form of FDI, together with the growing trend of the FDI. Both of them demonstrate positive and negative effects on the economy and banking sector in host countries.

\section{Advantages and Disadvantages of M\&A (as the form of FDI)}

There are advantages and disadvantages stemming from M\&A (FDI inflows) in (into) banking in transitional economies. Advantages can include the demonopolization of the banking sector (Papi, Revoltella, 1999; 9) and increasing the supply structure and quality of services. One of the crucial threats of FDI is to highlight the inferior position of domestic banks (Babic-Hodovic, 2003; 169). Citizens often have a higher level of trust in foreign banks, given the recent history of economic crises. This is more common in TE economies and there is a possibility that domestic banks could become completely dominated by foreign ones (Stiglitz, 1993; 19-52).

Investment results in $\mathrm{B} \& \mathrm{H}$, as well as those for Croatia and others, show that foreign banks increased the supply of retail banking very quickly after their entry into the market, thanks to the high level of technological development on the one hand, and mature financial markets in developed economies on the other. Data on deposit concentration in B\&H confirm this increase in supply (FBA, 2003).

We use the following theory based elements to analyze these issues.

$\checkmark$ Increased access to capital markets. Foreign bank entry facilitates access to international capital mar kets, as a consequence of the use of their networks; connections and positions give to the domestic economy (Papi, Revoltella, 1999; 9).

$\checkmark$ Advantages from the transfer of financial regula tion. FDI (specifically M\&A) can influence regula tory policy and, indirectly, can improve legal and regulatory efficiency, thus allowing the adoption of western standards in financial regulations and supervision (but only if their implementation is adapted to the domestic economic circumstances). Unfortunately, the reality is that elements of finan cial sector, financial markets, institutions and instruments from abroad, are very often uncritical ly accepted. This process takes place without adopting norms or regulations or without their implementation in the same way as in developed economies. Examples include creditor protection, mortgage lending, etc. (Babic, Pufnik and Stucka, 2001; 3-4).

$\checkmark$ Increased financial strength. Direct foreign invest ment and M\&A leads to increased financial strength of banks with foreign capital participation and support in solving problems of internal effi ciency.

$\checkmark$ Increased stability. Foreign banks can improve the stability of the domestic banking sector, especially since they can ensure more stable credit resources and make the banking system more resistant to shocks. Greater stability is reflected in the fact that branches and subsidiaries of big international banks can attract additional funds and capital if needed. This directly leads to a lower level of sys temic instability. This is especially interesting in the context of experiences in emerging markets. Empirical results from 15 emerging markets (Roldos; 2001; 15) show that each crisis of the banking system leads to a further increase in partic ipation and control by foreign banks in the domes tic banking sector. During the crisis it is necessary to intervene to further capitalize banks or to sell unsuccessful banks. Foreign banks are the only ones with resources to do so.

$\checkmark$ Positive indirect effects. However, these may be lost if the growing presence of foreign banks leads to bankruptcy (Babic, Pufnik and Stucka, 2001; 4). The $\mathrm{B} \& \mathrm{H}$ banking sector reality is characterized by 
mergers and acquisition between domestic banks and liquidation of some, as the result of competi tive pressure and legal restrictions such as capital requirements. As a result, the number of registered banks has decreased continually and the level of concentration in the banking sector increased.

\section{FDI FLOWS}

Global FDI flows have increased almost exponentially, from $\$ 59$ billion in 1982, to $\$ 208$ billion 1990, and to $\$ 648$ billion by 2004 (Table 2). Until 1990, nearly $80 \%$ of all FDI took place in developed countries. This proportion decreased in the 1990s to $60 \%$, and first fell below that number in 1996, as developing and transition economies' share increased (WIR, 2003). The share of SEE and Commonwealth of Independent States (CIS) countries grew from $1.0 \%$ of world FDI in 1990, to $3.8 \%$ in 2000 and 5.4\% in 2004 (Table 2).

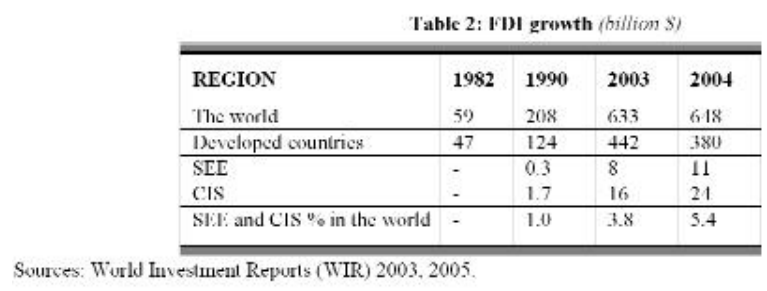

The growing participation of SEE countries is shown in Table 3. The index for SEE countries has gone from less than the world average in 1990 to double in 2003 and three times the world average in 2004. Developing and CIS countries have increased as well, but by much less.

\begin{tabular}{|c|c|c|c|}
\hline Region & 1990 & 2003 & 2004 \\
\hline World & 1.000 & 1.0000 & 1.000 \\
\hline Develuped counlries & 1.022 & 0.947 & 0.891 \\
\hline Deweloping enuntries & 0.977 & 1.187 & 1.353 \\
\hline South-last liurope and CIS & 0.955 & 1.254 & 1.787 \\
\hline South-East Europe & 0.835 & 2.273 & 3.064 \\
\hline CIS & 0.981 & 1.044 & 1.533 \\
\hline
\end{tabular}

\section{FDI flows in CEE and SEE}

More than half of European FDI in 2001 and 2002 was in non-European Union (EU) countries (Passerini, 2003; 2-36). Germany and Austria have been the most active investors in CEE, while Austria and Slovenia invested the most in SEE (UNCTAD, FIPA, 2004; 19). These numbers support the view that CEE and SEE have been of greatest interest to their immediate neighbors, and to one or two other countries that have a historical interest in the region.
FDI inflows to South-East Europe and the CIS recorded their fourth year of growth in 2004, reaching an alltime high $\$ 35$ billion (Table 2). Trends in inward FDI to the two regions differ somewhat, however, reflecting the influence of divergent factors. In South East Europe, FDI inflows started to grow rapidly in 2003, led by large privatization deals. In 2003-4 they nearly tripled from 2000, growing to $\$ 11$ billion. In the CIS, inflows grew from $\$ 5$ billion in 2000 to $\$ 24$ billion in 2004 (WIR, 2005), driven largely by the high prices of petroleum and natural gas. FDI inflows into the region are expected to grow further over the next few years. Net FDI inflows in to SEE are presented in Table 3.

Table 4. FDI inllows in CEE/ SEE countries (million s)

\begin{tabular}{|c|c|c|c|c|c|c|}
\hline FDI influws & 1999 & 2000 & 2001 & 2002 & 2003 & 2004 \\
\hline $\begin{array}{l}\text { SEE } \\
\text { Alhania }\end{array}$ & $\begin{array}{l}3,618 \\
143\end{array}$ & $\begin{array}{l}3,628 \\
204\end{array}$ & $\begin{array}{l}4,302 \\
135\end{array}$ & $\begin{array}{l}3.790 \\
178\end{array}$ & $\begin{array}{l}8,365 \\
343\end{array}$ & $\begin{array}{l}10,778 \\
1.514\end{array}$ \\
\hline $13 \&=11$ & 177 & 150 & 1.30 & 266 & 382 & 198 \\
\hline Bulgariat & 802 & 968 & 80.3 & 905 & $2,(6) 7$ & 2,188 \\
\hline Croalia & 1,120 & 1,085 & 1,107 & 1,126 & 2,612 & 1,076 \\
\hline IIungary & 3,065 & 2.191 & 3.580 & 2,540 & 874 & 3,653 \\
\hline Macedonia & 32 & 176 & 4.39 & 77 & 97 & 150 \\
\hline Monilenteyro & & & 10 & 85 & 44 & 62 \\
\hline Romania & 1,025 & 1,051 & 1,154 & 1,144 & 2,213 & 5,174 \\
\hline Serbial & 112 & 25 & 165 & 562 & 1,405 & 1,028 \\
\hline Slovakia & 701 & 2,058 & 1,400 & 4,007 & 549 & 1,250 \\
\hline Slovenia & 59 & 71 & 226 & 1,489 & -139 & 227 \\
\hline
\end{tabular}

Foreign investment in SEE before 1997 was largely opportunistic and undertaken by small foreign companies (UNCTAD, FIPA, 2004; 19). The two notable exceptions were the Austrian banks' considerable efforts to expand into SEE, and Slovenia's early start. Although most of Slovenia's FDI went to Croatia, it was one of the few countries that also invested in $\mathrm{B} \& \mathrm{H}$ and Macedonia (WIR, 2005). In Bulgaria and Romania, FDI doubled in 2003 when a date was set for EU admission, and more than doubled again in 2004 in Romania. Only Slovenia in 2002, Serbia in 2003 and Albania in 2004 show a similar jump in FDI in a single year. Slovakia has had exceptional years, but shows more variation than the others.

\section{Sectoral composition and forms of FDI in B\&H}

FDI in the SEE countries, along with most transition economies (TEs) is characterized by an increasing proportion of FDI in banking and infrastructure services, e.g., telecommunications, water, electricity, and relatively smaller amounts of FDI in business services and research and development (UNCTAD, FIPA, 2004; 22).

This is due to the fact that, in many countries, there was a very significant liberalization and removal of 
discriminatory barriers against foreign investment in the banking and financial sectors. These were removed to create a stronger, more efficient, financial system and to lower cost levels for bank re-capitalization and restructuring in a post-crisis period. For example, after 1997, FDI flows to Bulgaria, Romania and Croatia increased dramatically, due to an improved political and business climate in these countries brought by structural reforms, as well as the expansion and opening of their financial sector to FDI.

Harmonization and mutual recognition of regulations between economies are also important elements in the growing level of FDI in the financial sector. Growing FDI in services, specifically in the banking area, was influenced by the following (Babic-Hodovic, 2003; 152-153):

$\checkmark$ Globalization of the financial services industry which resulted in growing competition between different non-bank sources of credits and financial services (especially in the insurance market) which, in turn, led to the continuing consolidation of banking systems in both mature and emerging markets (Roldos, 2001; 7) and even to the need to open new markets.

$\checkmark$ Foreign banks' interest in emerging markets is part ly explained by the potential economies of scale or scope from technological advantage as well as the advantage of early entry in product or service life cycles.

$\checkmark$ A regional marketing orientation, where many banks focused on a specific region, guided by lan guage and cultural connections. For example, in
$\mathrm{B} \& \mathrm{H}$ there are Austrian banks, in Croatia, Italian banks, etc. This strategy is the result of regional marketing orientation.

The main form of FDI in financial sector of B\&H was mergers and acquisitions. Looking at the numerous foreign banks, working on B\&H market, we can see that most of them chose acquisition as the form to start with the operation.

Very important motive for acquisitions instead of new venture was the fact that all acquired domestic banks had strong wide network of branches at B\&H market and work force, new venture never get in the short period.

This trend, together with the legal regulation of minimum level of bank capital, forced, small domestic banks to start with mergers and acquisitions to get required level of capital and to survive strong competition on the market. (Look at Appendix 1 for detailed information).

FDI in the financial sector in CEE reached $13.6 \%$ of the total in 1999. This is the highest level of FDI in one particular area among transition economies (Babic-Hodovic, Buric, 2005; 1413). This higher level of FDI in the financial sector clearly affects the change in the ownership structure in banking and gave increasing control over bank assets and bank activities to foreign banks in Central Europe. The participation of foreign capital in bank assets in CEE countries was around $70 \%$ in 1999-2001, but more than $90 \%$ in some countries by 2004 (Table 5).

Table 5: The (.FF/SF. Ranking Market (Foreign Bank Participation)

\begin{tabular}{|c|c|c|c|c|c|c|c|c|c|c|c|}
\hline \multirow[b]{2}{*}{2004} & \multirow[b]{2}{*}{ No. of banks ${ }^{1}$} & \multicolumn{2}{|c|}{ Murket share ${ }^{2}$} & \multicolumn{2}{|c|}{ Totil ussets } & \multicolumn{3}{|c|}{ Louns } & \multicolumn{3}{|c|}{ Deposits } \\
\hline & & 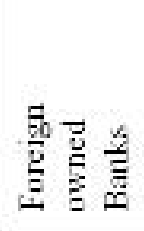 & 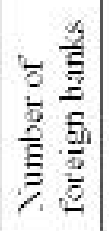 & 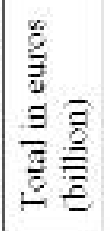 & $\overrightarrow{\mathrm{G}}$ & 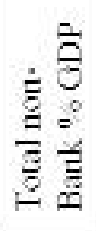 & 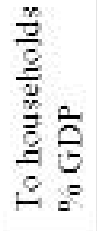 & 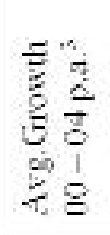 & 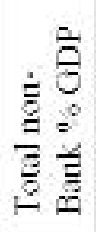 & 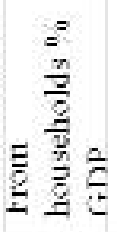 & 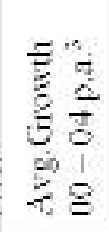 \\
\hline$|3 \& z| 1$ & 33 & 81 & 17 & 4.9 & 72.3 & 42.9 & 20.2 & 64.6 & 38.6 & 17.9 & 64.2 \\
\hline Crustial & 37 & 91 & 13 & 31.9 & 110.8 & 58.9 & 31.5 & 20.0 & 75.0 & 30.2 & 18.2 \\
\hline Montencero & 10 & 31 & 3 & 0.1 & 28.9 & 18.1 & 1.8 & 141.5 & 15.8 & 5.2 & 21.3 .4 \\
\hline Scrbia & 43 & 38 & 11 & 7.0 & 39.2 & 20.2 & 9.7 & 27.5 & 21.4 & 9.5 & 84.1 \\
\hline IIungary & 38 & 63 & 27 & 59.3 & 73.3 & 49.7 & 19.3 & 57.8 & 47.2 & 21.0 & 12.7 \\
\hline Slovakin & 21 & 6.3 & 16 & 29.1 & 87.8 & 33.4 & 8.8 & 2.7 & 61.5 & 27.7 & -7.9 \\
\hline Slov enit & 18 & 20 & 6 & 240 & 91.2 & 49.1 & 12.3 & 168 & 569 & 37.2 & 13.4 \\
\hline
\end{tabular}

Sources: BA - CA Economics Department (2004; 18), Country Central Bank and Banking Agency Reports. 
1. Credit cooperative are counted as banks

2. Majority interests are counted as $100 \%$

3. Local currency, from 2001 for Serbia and Montenegro, total lending and deposits for Slovakia and Slovenia.

Prospects for future FDI and M\&A are related to anticipate growth in lending and deposits. In spite of rapid growth in most of these countries, total deposits and lending, particularly household lending has room for growth. Based on research by one of the Austrian banks, the level of loans and deposits in most of the region will be several hundred percent higher in the next decade. (BA-CA Economics Department, 2004; 32-39). In the same time we can expect further competition for the position in the region, which will influence on the growing number of mergers and acquisitions in the region.

\section{BANKING SECTOR DEVELOPMENT IN BOSNIA AND HERZEGOVINA}

In order to analyze the real effects and consequences of FDI on the banking sector of B\&H and comparing to the countries in the region we use several indicators: total assets of the banking sector as a per cent of GDP, interest rates, the structure of deposits and loans and profitability.

\section{Total Banking Assets, concentration of banking sector and Foreign Participation}

At the end of the December 2004, total bank assets in B\&H were KM 1.6 billion, or $81 \%$ of GDP (Table 6). This represents growth from $33 \%$ of GDP at the end of 2000. The banking assets of the biggest bank, the Austrian Raiffeisen bank d.d. BH, accounted for nearly $20 \%$ of total banking assets. The five largest banks accounted for more $64 \%$ of total banking assets at the end of 2004. Three of these five banks were direct subsidiaries of Austrian banks (Reininger and Walko, $2005 ; 110-120)$. These ratios point to a high degree of concentration in the banking sector. It may be expected that consolidation will continue in the next few years.

Increased concentration in the banking sector can lead to the monopolization of the sector. However, with the large number of small banks in B\&H in the 1990s, the level of concentration is not yet high enough to be of concern. In general though, it is important for emerging markets to ensure anti-monopolistic laws and regulations that would prevent closing of the circle of efficiency and structure supply, which was previously broken with the foreign banks entry.

Table 6: Banking Assets as \% of GDP and Foreign Bank Participation

\begin{tabular}{|l|l|l|l|l|l|l|}
\hline Banking Assets, \% of GDP \\
\hline Country & 1999 & 2000 & 2001 & 2002 & 2003 & 2004 \\
\hline B\&H & 30.0 & 33.1 & 43. & 48.5 & 59.2 & 72.3 \\
\hline Croatia & 65.8 & 73.1 & 89.4 & 92.3 & 105.8 & 110.8 \\
\hline Montenegro & - & - & 35.0 & 27.8 & 25.5 & 28.9 \\
\hline Serbia & - & 54.2 & 22.4 & 24.4 & 28.2 & 39.2 \\
\hline Hungary & 66.86 & 68. & 68.4 & 69.3 & 77.9 & 73.8 \\
\hline Slovenia & 42.5 & 50.5 & 62.5 & 70.4 & 81.7 & 91.2 \\
\hline Slovakia & - & - & 91.98 & 90.90 & 82.0 & 87.8 \\
\hline & & & & & \\
\hline \%of Foreign & Participation in Banks Assets & & & \\
\hline Country & 1999 & 2000 & 2001 & 2002 & 2003 & 2004 \\
\hline B\&H & 3.8 & 21.6 & 65.3 & 76.7 & 79.9 & 80.9 \\
\hline Croatia & 40.3 & 84.1 & 89.3 & 90.2 & 91 & 91.2 \\
\hline Montenegro & - & - & 3.3. & 16.2 & 23.4 & 31.1 \\
\hline Serbia & - & 0.5 & 13.2 & 2.7 & 38.4 & 37.7 \\
\hline Hungary & 61.8 & 67.1 & 66.5 & 85.0 & 83.5 & 63.0 \\
\hline Slovenia & 4.9 & 15.3 & 15.2 & 16.9 & 18.9 & 20.5 \\
\hline Slovakia & 24.1 & 42.1 & 78.3 & 84.1 & 96.3 & 96.7 \\
\hline
\end{tabular}

EBRD Transition Report, 2005, Country Central Bank and Banking Agency Reports. 
Table 6 gives data on total banking assets in the region as a percent of GDP, as well as the participation of foreign banks in assets for the last 6 years. The highest level of foreign participation is in Slovakia at $96.7 \%$ and Croatia at $91.2 \%$. Hungary had $85 \%$ foreign ownership in 2002 , falling to $63 \%$ by 2004 . The lowest level is in Slovenia at about $20 \%$. The main reason is protection of the banking sector in Slovenia as opposed to reform and privatization in Croatia, Hungary and Slovakia.

The structure of participation of foreign banks in banking assets corresponds to the participation of total banking assets in GDP. Countries, which have higher participation rates, also have higher levels of foreign ownership (Croatia, Slovakia, Hungary and B\&H, versus Serbia and Montenegro). The only exception is Slovenia, which has a relatively low level of foreign participation in banking assets, but has a very high level of banking assets in GDP.

\section{Interest rates}

Since 2000, interest rates on deposits in B\&H, both in $\mathrm{KM}$ and euro, have decreased dramatically (Table 7). Greater competition among banks, especially those which are foreign-owned, reform and consolidation of the banking sector, along with large increases in savings deposits, have contributed to a decline in $\mathrm{KM}$ deposit rates to an average of around 3.7\% in 2004. Despite the declining trend, these rates are still higher than those in the countries using the euro, to which the $\mathrm{KM}$ is pegged under the Currency Board arrangement. $\mathrm{KM}$ interest rates on deposits and loans are also higher than those in other countries that have currency boards pegged to the euro, but the differences are decreasing. In 2004, average lending rates in $\mathrm{B} \& \mathrm{H}$ came down to around $12 \%$, which is comparable to, or slightly lower than, similar rates in neighboring SEE countries that do not have currency boards (Croatia $11.7 \%$, Serbia $14.6 \%$ ).

Despite reductions in interest rates, prevailing opinion among the public and entrepreneurs seems to be that lending rates are still too high and maturities too short in the countries of former Yugoslavia. Real interest rates in BH were relatively high in 2004 (around $10 \%$ ), after discounting year-on-year inflation of around $1 \%$, and similar in Croatia. Not unexpectedly, bankers think that the present levels of rates on loans are justified, given the general risk environment. The decline of nominal lending rates in the past 3 years is probably more a result of the competition among banks than an improvement of the business environment. The growth of healthy local enterprises is slow and reliable corporate clients are hard to find as a result of ever-present smuggling and the grey economy. This, of course, also affects interest rates. The high perceived risk of the country's political and business environment also affects the price of capital on international markets for local banks. However, in this regard, the sovereign credit rating of $\mathrm{B} 3$ with a positive outlook (B3+), which was given to $\mathrm{B} \& \mathrm{H}$ by Moody's in March 2004, will likely improve the terms on which banks in $\mathrm{B} \& \mathrm{H}$ are able to borrow internationally.

Looking at the table 5 we can conclude that the entry of foreign banks did not affect the level of interest rates in SEE countries, at least to the same extent as in

T'uhle 7: Average Depesit und I snding Ratus

\begin{tabular}{|c|c|c|c|c|c|c|c|c|c|c|c|}
\hline & \multicolumn{5}{|c|}{ Dspesil ralex } & \multicolumn{6}{|c|}{1 snding rales } \\
\hline & 20000 & 20191 & 201012 & 200.3 & 2004 & 2000 & 20141 & 20142 & 20013 & 20144 & $\begin{array}{l}2004 \\
\text { Inf } \\
\text { rate }\end{array}$ \\
\hline $\begin{array}{l}\text { B\&H Fcd. } \\
\text { and } \mathrm{kS}\end{array}$ & $\begin{array}{l}147 \\
37\end{array}$ & $\begin{array}{l}61 \\
32\end{array}$ & $\begin{array}{l}45 \\
1.9\end{array}$ & $\begin{array}{l}40 \\
1.5\end{array}$ & 37 & $\begin{array}{l}30.5 \\
12.1\end{array}$ & $166^{1}$ & $\begin{array}{l}12.7 \\
12.8\end{array}$ & $\begin{array}{l}109 \\
11 \%\end{array}$ & 117 & $\begin{array}{l}(03 \\
\text { Fed. } \\
2.2 \\
\text { KS }\end{array}$ \\
\hline Choatia & 21 & 28 & 1.6 & 1.7 & 1.8 & 10.3 & 9.91 & 11.2 & 11.8 & 117 & 21 \\
\hline Muntericisivi & 1.1 & 1.9 & 73 & 10 & 3.7 & 17.9 & 29.2 & 20.3 & 17.3 & 15.6 & 13 \\
\hline Suthit & 6.3 & 1.1 & 26 & 27 & 3.6 & $\gamma / 9$ & 32.1 & 19.2 & $14 . x$ & 14.6 & 13.7 \\
\hline Ilurizary & 11.0 & 1000 & 9.9 & 9.8 & 11.3 & 3.2 & 6,2 & 5.9 & 6.1 & 36 & 6.8 \\
\hline Slowalia & 7.2 & 3.2 & 1.6 & 1.1 & 26 & 7.2 & 3.2 & 1.6 & 1.1 & 26 & zs \\
\hline Sloncaia & 6.5 & 6.2 & 3.6 & 1.5 & 3.1 & 10.6 & 9.3 & x. 9 & 7.3 & 3.6 & 36 \\
\hline
\end{tabular}


CEE countries. Despite the positive evaluation of the stability of the banking sector in the region (UNCTAD, FIPA, 2003; 23), interest rates are still more than double those in the Euro zone.

\section{Structure of Deposits \& Loans}

In the period between 2000 and 2004, the total loan portfolios of Federation banks rose from KM 1,308 million to KM 4,422 million, an average increase of $38 \%$ per year. In the RS, bank loan portfolios grew at an average rate of $28 \%$ per year during the same period, from KM 344 million to 729 million (FBA, BARS, 2001, 2005). Rapid credit expansion was particularly obvious in case of households. In 2002, banks' net lending increased by 55\% (CBBH, 2004), followed by $35 \%$ growth in 2003 and 34\% in 2004 (Table 8). Some believe that the market for consumer loans is beginning to be saturated. Other transition countries, especially those having made the most progress in reforming their economies, have also experienced rapid credit growth. However, rapid credit growth can be a leading indicator of future losses and difficulties for a banking system. Credit growth in B\&H has been funded mainly from an increase in deposits as well as increased funding from abroad. This rapid growth in lending is now slowing down (to 20\% in 2003 and $16 \%$ in 2004 (Table 8)), but the increase that has already occurred is likely to result in some credit problems for banks. As we can see from Table 8, there is little change in the structure of deposits, but large changes in the composition of loans. Private companies' share increases from $24 \%$ to $44 \%$ in just 2 years, and lending to individuals increased from $34 \%$ to $44 \%$, both at the expense of State owned companies.

The main constraint on investment by the state-owned enterprise sector is its high level of indebtedness, along with illiquidity. Having written off their old loans to the state sector during the past few years, commercial banks, which are now mostly private and predominantly foreign-owned, have opted to lend selectively to privately owned companies. They have also expanded their lending to households, for the purchase of consumer durables, for house repair or purchase. This is a logical portfolio shifts by banks, but it has led to complaints from the enterprise sector whose access to bank credit is difficult, and has also fuelled imports of consumer goods. The advantages of improved access to bank credit by corporate borrowers who have credible business plans and cash flow that is demonstrably sufficient to repay their debts are obvious. Commercial banks will be well advised to maintain strict credit standards, in order to avoid incurring new bad debts.

\section{Profitability (ROA and ROE)}

The data on profitability show an improving trend in the Federation of $\mathrm{B} \& \mathrm{H}$, with the RS moving the other way until 2004 (Table 9). Both showed losses until 2002. The poor profitability of many banks may be explained by a low level of efficiency, specifically an excessive number of employees for the scale of their operations and substantial provisions for loan losses, accompanied by the costs of expanding their branch

Table 8: Structure of depoxit and lendiny by secturs

\begin{tabular}{|c|c|c|c|c|c|c|}
\hline & $\begin{array}{l}12 / 31 / 2002 \\
\text { Amuant }\end{array}$ & Share: & $\begin{array}{l}12 / 31 / 2003 \\
\text { Amount }\end{array}$ & Share: & $\begin{array}{l}12 / 31 / 2004 \\
\text { Amount }\end{array}$ & Share \\
\hline Gorernucat & 564 & $15^{\circ} \%$ & 709 & $16^{\circ} \%$ & 769 & $14 \%$ \\
\hline Stale-owned asmpnanie: & 456 & $12 \%$ & 679 & $14 \%$ & 830 & $15 \%$ \\
\hline I'rivale companims & 127 & $20 \mu_{n}$ & $\mathrm{~N} / 2$ & $16 \%$ & 1.0025 & $18 \%$ \\
\hline Non-protit oreanizations & 128 & $3 \%$ & 124 & $3 \%$ & 147 & $3 \%$ \\
\hline Gilnzen: & 1,621 & $44^{\circ} n$ & $1,97.6$ & $44^{\circ} n$ & 7,488 & $4^{5 n}=$ \\
\hline Ohus & 227 & $6 \%$ & 216 & $6 \%$ & 339 & $6 \%$ \\
\hline Total deposits & 3,724 & $100 \%$ & 4,366 & $100 \%$ & 5,577 & $100 \%$ \\
\hline Goxernmeat & 55 & $1 \%$ & 40 & $1 \%$ & 40 & $10 \%$ \\
\hline Stale-nw ned swmpanes: & $1,25.5$ & $709 \%$ & 1,167 & $73 \%$ & 695 & $12 n=$ \\
\hline I'rivale companics & 1.112 & $31 \%$ & $1,8(3)$ & $36{ }^{\circ} \mathrm{u}$ & 2.182 & $12 \%$ \\
\hline Non-protit organizations & 18 & $\omega_{0}$ & 11 & $\omega_{6}$ & 13 & $0 \%$ \\
\hline Colszen: & 1456 & $74^{\circ} \%$ & 1.966 & $7 x^{n} \circ$ & 2,677 & $+4^{n} 6$ \\
\hline Ghis & 36 & $1 \%$ & $\sqrt{2}$ & $1 \%$ & 2 & $1 \%$ \\
\hline Total lending & 4,281 & $100 \%$ & 5,122 & $100 \%$ & 5,935 & $100 \%$ \\
\hline
\end{tabular}


networks (FBA, 2004). Table 9 also shows data on ROA and ROE for countries in the region. Interestingly, several countries show a decreasing trend in ROA and ROE, which is the opposite of the banks in $\mathrm{B} \& \mathrm{H}$. ROA is more stable over these 5 years. ROE increases over the period in Croatia, Hungary, Slovakia and Slovenia.

\section{CONCLUSION}

Reform and privatization of the banking sector have brought reputable foreign banks to Bosnia and Herzegovina and the region. Early arrivals were Raiffeisen Bank and Volksbank (Austrian banks), Unicredito bank (Italy), Ziraat Bank (Turkey) and Zagrebacka Banka* (Croatia). More recently, substantial investments in B\&H's banking system have been made by Hypo Vereinsbank [HVB] (Germany), Hypo Alpe-Adria-Bank (Austria) and Nova Ljubljanska Banka** (Slovenia). This has happened largely through acquisition of local banks under the Entity governments' bank privatisation programs. However, several foreign banks (Turkish Ziraat bank, Volksbank, Zepter, Balkan Investment bank...) have set up new fully owned operations. Further consolidation by foreign banks of their respective interests in $\mathrm{B} \& \mathrm{H}$ and the region, to consolidate their holdings and enhance their competitive position is likely.

However, this presents a risk to financial stability in the region, with the possibility of problems in one country spreading to others. This risk is accentuated by the large and growing concentration of ownership in the banking sector, particularly from the domination by the Italian bank, Unicredito. This bank has businesses throughout the region, but in four countries (Croatia, Bulgaria, B\&H, and Poland) it has a significant market share. $* * *$ Whereas for the general popu- lation, the arrival of foreign banks has undoubtedly boosted their confidence in the banking system, the full effects of this development on the banking and enterprise sector still remain to be seen. Initially, several of the foreign banks that bought existing banks simply adapted to the local operating environment, rather than requiring that their bank operations be run in accordance with the stringent corporate guidelines enforced in their home countries. This was especially case in B\&H. However, as competition intensified, foreign banks are introducing expertise from their headquarters, with a view of implanting their own corporate culture. They are undertaking significant staff training, including language training. Several banks have brought foreign account executives into the local market, as well as training relatively senior local staff members to be managers within the wider bank system.

Interest in the banking sector in the region is still high. Investment is profitable for the simple reason that, in spite of the high growth in lending, the share of banking sector assets to GDP in the region is still relatively low, compared to the European Union. This share is the highest in Croatia, at 110,8\%, which is still low compared to an average of $209 \%$ in the European Union. This indicates that there is more space for expansion of the banking sector in the region.

Overall, the effects of increasing M\&A (FDI) in the banking sector in $\mathrm{B} \& \mathrm{H}$ and the region has been positive. These include increased confidence in the banking system, increased banking deposits and assets as the foreign share has increased a decline in lending rates and a change in the structure of lending towards households, a previously underserved market. The price for this has been increased concentration, lead-

Table 9: Profitability of Banks

\begin{tabular}{|c|c|c|c|c|c|c|c|c|c|c|}
\hline & \multicolumn{5}{|c|}{ RO.I } & \multicolumn{5}{|c|}{$\mathrm{ROE}$} \\
\hline & 2000 & 2001 & 2002 & 2003 & 2004 & 2000 & 2001 & 2002 & 2003 & 2004 \\
\hline $\begin{array}{l}\mathrm{B} \& \mathrm{H} \\
\text { liodelithixI }\end{array}$ & -129 & -48 & 047 & $10 \%$ & & -895 & -514 & 2,57 & 833 & \\
\hline $\begin{array}{l}\text { I3sEI| } \\
\text { l2\$; }\end{array}$ & -0.4 & -0.4 & -0.1 & -3.6 & 0,8 & -14 & -1.5 & -15.1 & -15.6 & 13.5 \\
\hline Crostia & 1.3 & $0 \%$ & 1.3 & 1s & 1.7 & 10.7 & 6.6 & 13.7 & 11.5 & 16.1 \\
\hline Morilernigys & & 6. 7 & 1 & 1.6 & 0.3 & & 1.1 & 1.5. & 6.5 & 1.2 \\
\hline Sicrbia & 6.3 & 1.1 & 26 & $2 \%$ & 3.6 & $7 / 9$ & 32.1 & 192 & 11.8 & 11.6 \\
\hline Iluagity & 1.3 & 1.6 & 17 & 1.9 & 2.3 & 167 & 19.7 & 198 & 23.6 & 298 \\
\hline Slovenia & U. $x$ & I.I & as & 1.1 & 1.0 & $7 \mathrm{~s}$ & 11.1 & 18 & 13.3 & 129 \\
\hline Slovakis & 0.1 1 & 0.5 & 1.2 & 1.1 & 1.1 & 1.9 & 8.3 & 24.9 & 28.0 & 297 \\
\hline
\end{tabular}

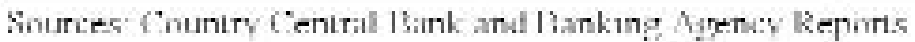



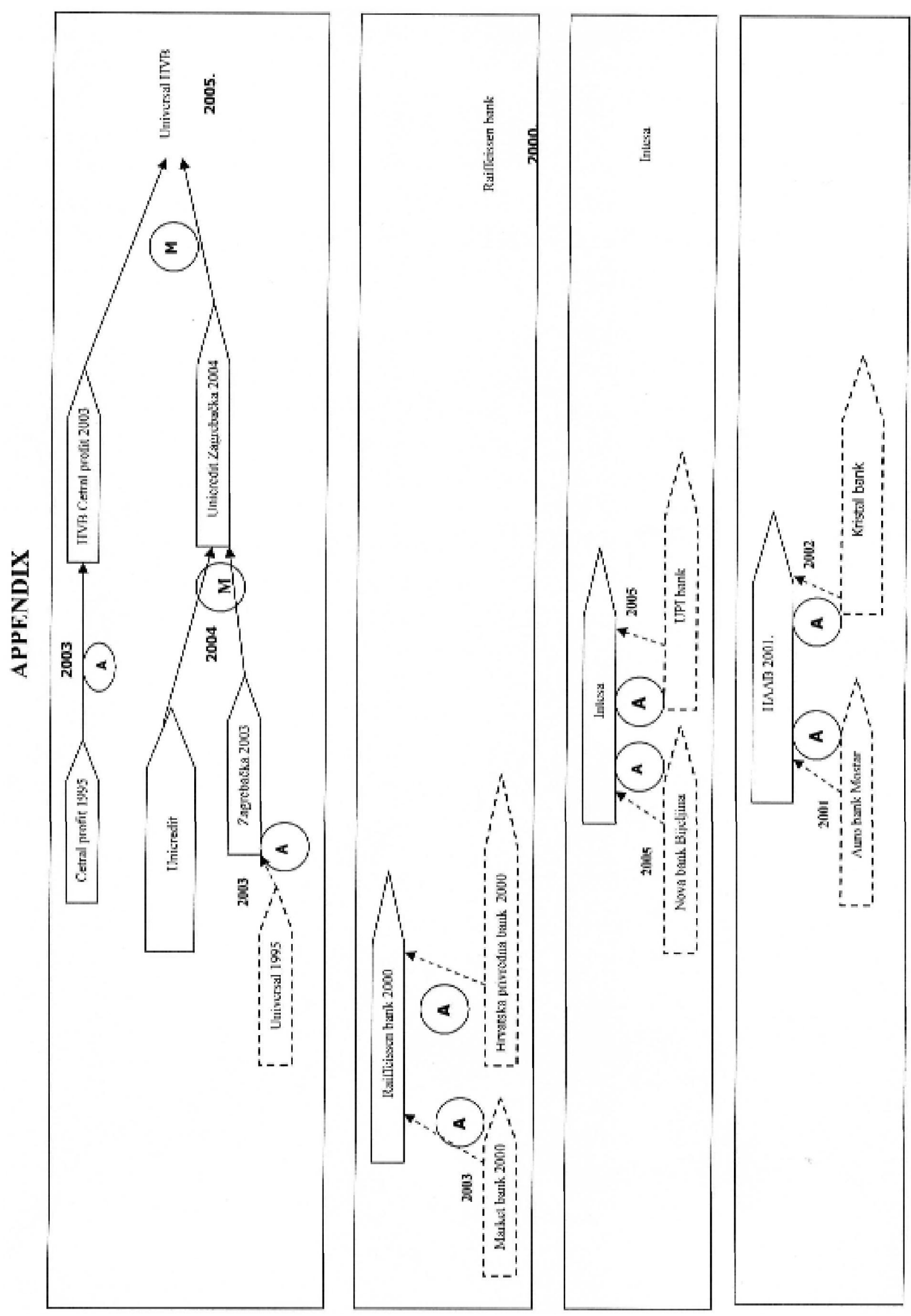


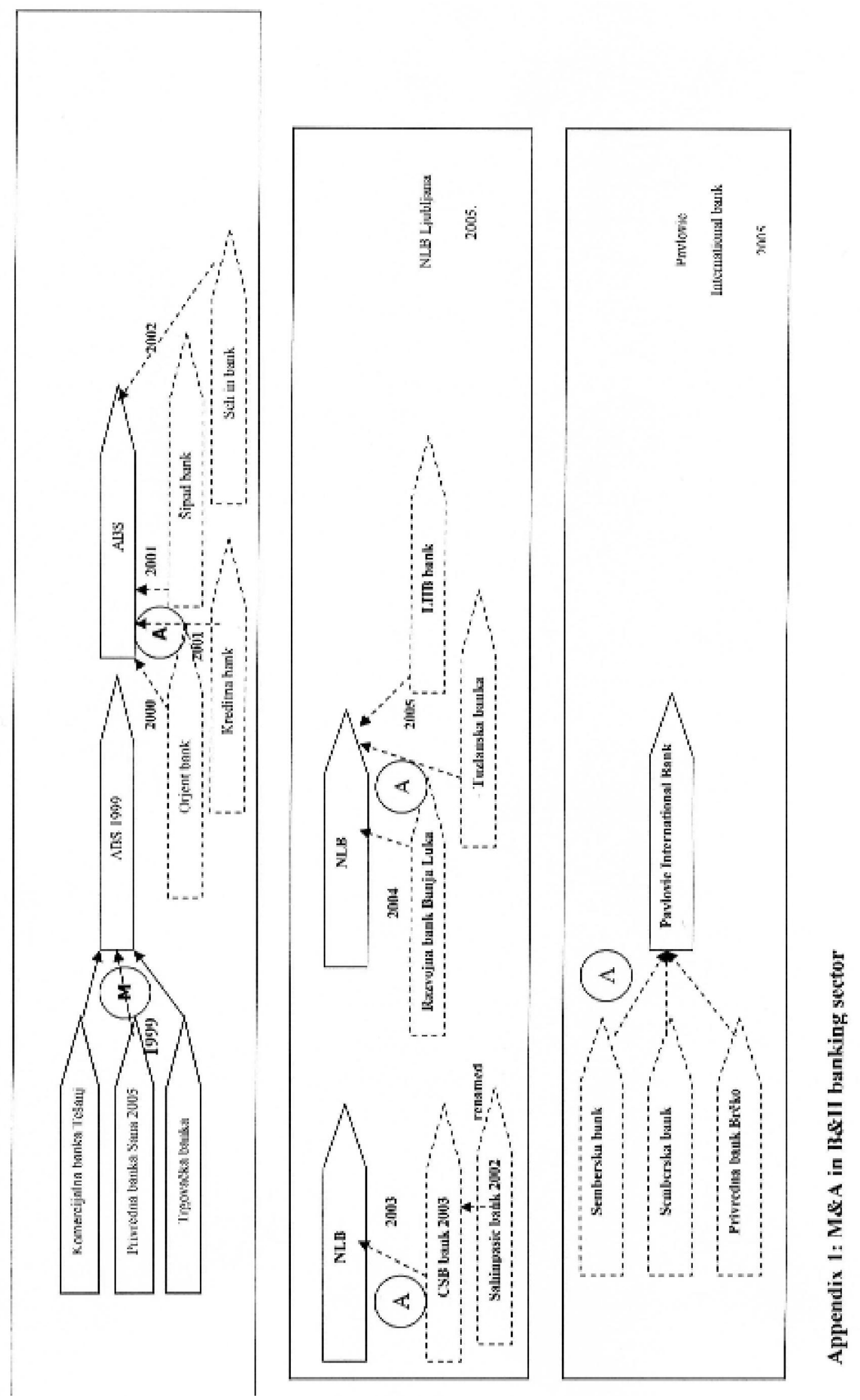


ing to a regional dependence on a decreasing number of foreign banks, with a possible increase in systemic risk and monopolistic behavior. Still, the lessons are clear, reform and the opening up of domestic markets has spurred growth and development of the banking sector. However, there is a need for countries to insist on good corporate behavior, as well as careful monitoring of potential anti-competitive behavior.

\section{REFERENCES}

Annual Report (2002, 2004). National Bank of Serbia

Annual Report (2002, 2004). Slovak Central Bank.

Babic, A. Pufnik, A. Stucka T., (2001) "Theory and reality of foreign direct investment in the world and transition economies with special accent of Croatia", Croatian Central Bank, 2001., pp 1-29;

http://www.hnb.hr/publikac/pregledi

Babic -Hodovic V. and Buric, M. (2005). The Impact of Direct Foreign Investment on Quality of Services and the Development of Banking Sector of Transitional Economies - Bosnia and Herzegovina case. Proceedings of 6th International Conference Enterprise in Transition. Split, Bol, May 26-18., pp 1409-1433.

Babic-Hodovic, V. (2003). FDI and Banking Integration in Bosnia and Herzegovina - Influences on the Economic Growth in BH. Conference "Economic Development and Reconstruction Policies in South -East Europe: Regional Cooperation, Trade and Foreign Investment. Inter-University Centre, Dubrovnik. 10-12 April

Babic-Hodovic, V. (2003), Efekti direktnih stranih ulaganja u bankarski sistem zemalja u tranziciji, Zbornik radova, Ekonomski fakultet u Sarajevu, 149182, Sarajevo, 2003.

BA - CA Economics Department, (2004) South East Europe: The Growth Market With the Growth Market, Euromoney Conference Dubrovnik, October 2004, pp 18, based on BA-CA Economics Department Sources.

Banking Sector in Serbia, First Quarter Report (2005). National Bank of Serbia.

Banks Bulletin (2001, 2002, 2003, 2004, 2005). Croatian National Bank. Nos. 3, December, 5 December, 7 October, 9 December, 10 July.

BARS (2001, 2005). Informacija o Bankarskom Sektoru Republike Srpske za Period 01.01.-31.3.2005 godine, za Kvartal 2001. godine. Banking Agency, Republic of Srpska. Banja Luka

Central Bank of Bosnia and Herzegovina (2004). Annual Report 2004. 
Economist Intelligence Unit (2003), EIU Report

EU FDI flows with extra -EU countries didn't nearly 40\% in 2002 (2002). EU Trade Press Release, 4. July. http://europa.eu.int/comm/trad.

FBA (2001, 2003, 2004, 2005). Informacija o bankarskom sistemu Federacije B\&H, 31.12.2001, 31.12.2003, 21.12.2004, 31.03.2005. Agencija za Bankarstvo Federacije Bosne i Hercegovine, Sarajevo.

Foreign Investment Boom in Transition Economies Will Withstand Global Slowdown (2003). Economist Intelligence Unit.

Mathieson D.J., and Roldos J. (2001). Foreign Banks in Emerging Markets. In Litan, Masson and Pomerleano, (Eds.), Open Doors: Foreign Participation in Financial Systems in Developing Countries. Brookings Institution Press, Washington, DC.

Papi, L. Revoltella, D. (1999), Foreign Direct Investment in the Banking Sector: A Transitional Economy Perspective, Development Studies Working Papers,www.dagliano.uni-bocconi.it, http://www2.qeh.ox.ac.uk/. Pp 1-34

Passerini, P. (2003). EU FDI with Extra-EU decreased again in 2002: First results FDI 2002. Eurostat Statistics in Focus, Theme 2-36/2003, 1 July.

Poslovanje Banaka u 2003, 2004 (2003, 2004). Central Bank of Montenegro.

Reininger, T., Walko, Z (2005). The Croatian Banking System. Banking Sector and Financial Stability Report, No. 9, Oesterreichische Natinalbank (ONB), http://www.oenb.at., pp 110-126

Report on Banking Supervision in 2003 and First Half of 2004 (2004). Bank of Slovenia.

Report of Financial Stability (2005). Magyar Nemzeti Bank (Hungarian National Bank). stab_jel_mellelket_20051010, December.

Roldos J. (2001). FDI in Emerging Markets Banking Systems. In OECD Global Forum on International Investment: New Horizons and Policy Challenges for Foreign Direct Investment in the 21st Century. Mexico City, November., pp 1-19.
Stiglitz, J.E. (1993), The Role of the State in Financial Markets, Proceedings of the World Bank Annual Conference on Development Economies, 19-52

Tesche, J. (2002). Banking Reform in Bosnia and Herzegovina. In Z. Sevic (Ed). Banking Reform in the Balkans. Edward Elgar, London.

Transition Report 2005: Business in Transition (2005). EBRD, London.

United Nations Conference on Trade and Development (UNCTAD) and Foreign Investment Promotion Agency of Bosnia and Herzegovina (FIPA), (2004), Investment Promotion Strategy for Bosnia and Herzegovina, Draft Advisory report prepared by UNCTAD's Advisory Services on Investment and Training (ASIT), Geneva, Switzerland, November 2004

U.S. Department of State (1995). Dayton Peace Accords: General Framework Agreement for Peace in Bosnia and Herzegovina. Office of Public Communication, Bureau of Public Affairs, December, Washington, DC.

Walter, Ingo, (2004) Mergers and Acquisitions in Banking and Finance, Oxford University press,

World Investment Report 2003: FDI Policies for Development: National and International Perspectives (2003). UNCTAD, United Nations, New York and London.

World Investment Report 2005: Transnational Corporations and the Internationalization of $R \& D$ (2005). UNCTAD, United Nations, New York and London.

Notes

* Zagrebacka banka d.d. Zagreb, Croatia, is owned $96,2 \%$ by a consortium of UniCredit Italiano and Allianz A.G.

** Nova Ljubljanska Banka is owned $34 \%$ by the KBC Bank and Insurance Group of Belgium

*** In Croatia, the share is $35 \%$ after selling Splitska banka. In B\&H it has a 30\% share, in Bulgaria, 25\%, and in Poland, 21\%. 